\title{
Morphometric Assessment of Two Watersheds of High Atlas of Morocco Using Remote Sensing and GIS Techniques: What Is the Impact on Surface Water Availability?
}

\author{
Lahcen Mostakim1,2, Fadoua El Qorchi'2, Fatima Zahra Guennoun1,2, Soumia Moutaouakil1,2, \\ Elisabeth Berger ${ }^{3}$, Mohamed Ghamizi ${ }^{1,2}$
}

${ }^{1}$ Research Center of the Museum of Natural History, Cadi Ayyad University, Marrakech, Morocco

${ }^{2}$ Laboratory of Water, Biodiversity and Climate Change, Faculty of Sciences Semlalia, Cadi Ayyad University, Marrakech, Morocco

${ }_{3}^{3}$ ES Landau, Institute for Environmental Sciences, University Koblenz-Landau, Landau, Germany

Email: mostakim.lahcen@gmail.com

How to cite this paper: Mostakim, L., El Qorchi, F., Guennoun, F.Z., Moutaouakil, S., Berger, E. and Ghamizi, M. (2021) Morphometric Assessment of Two Watersheds of High Atlas of Morocco Using Remote Sensing and GIS Techniques: What Is the Impact on Surface Water Availability? Journal of Geographic Information System, 13, 631-642.

https://doi.org/10.4236/jgis.2021.136034

Received: October 24, 2021

Accepted: November 28, 2021

Published: December 1, 2021

Copyright $\odot 2021$ by author(s) and Scientific Research Publishing Inc. This work is licensed under the Creative Commons Attribution International License (CC BY 4.0).

http://creativecommons.org/licenses/by/4.0/

\begin{abstract}
The abundance or scarcity of surface water in a watershed is related to environmental factors including its morphology, substrate type, rainfall, slope, and exposure to moist air masses. The combination of these characteristics explains the hydrological behavior of the river network, knowledge of which is important for water resources management. Geographic Information System and Remote Sensing are efficient tools to assess the morphometric characteristic in a watershed. Using these tools, the physical characterization of the two water basins located on either side of the High Atlas of Morocco was investigated in this study. The results show that the Upper Draa basin is characterized by an elongated shape, with a drainage density of $0.14 \mathrm{~km} / \mathrm{km}^{2}$. Altitudes and slopes vary little and slopes are oriented in most cases towards the southeast $(27.34 \%)$. Substrate is mostly permeable, which promotes infiltration and aridity of the soil. This contrasts with the Zat basin that is characterized by very variable elevations and slopes, and slopes are mainly exposed to the North and North-West (30.42\%), which therefore favors strong runoff and a very high flow velocity. The hydrological contrast observed in the two basins impacts the human use of surface water. These results effectively explain the hydrological behavior and provide managers with useful information for better management and decision-making regarding the two studied hydro systems.
\end{abstract}

\section{Keywords}

Basin, GIS, Morphometric Characteristics, Hydrological Behavior, Morocco 


\section{Introduction}

Currently, the management and preservation of water resources are major challenges in many regions of the planet [1] [2], especially in countries with arid and semi-arid climates where water resources have become increasingly scarce due to the combined effects of climate change and growing water needs for agricultural development and population growth. Like other African countries, the surface and groundwater water resources of Morocco have suffered significant degradation by different sources of liquid and solid pollution, accompanied by increased drought caused by climate change, over the past years [3] [4].

Knowing the morphometric characteristics of watersheds is crucial to the development of hydrological studies for better water resource planning and management [5] [6]. These characteristics have been extensively used in the analysis and the modelling of different hydrological and ecological phenomenon such as floods and soil erodibility [7] [8] [9], the estimation of the runoff depth and time of concentration of the flow in the basin [10] [11] [12] and the determination of the morphometric characteristics for assessing water resources in drainage basins [13] [14].

However, these water resources are influenced by geomorphological, orographic and climatic factors. The combination of these parameters control part of the water cycle and influence the abundance and scarcity of water resources. Traditional techniques used are based essentially on manual methods, and obtained results had thus far been unsatisfactory. However, the determination of the morphological and orographic parameters of a basin is feasible with GIS tools and Remote Sensing. Digital Elevation Model (DEM) coupled with Geographic Information System (GIS) techniques has been proved by several researchers to be a useful tool for morphometric analysis of watersheds [6] [7] [8] [9].

The Zat basin and the Upper Draa basin are two watersheds located on each side of the mountain ranges of the High Atlas-Morocco which constitutes an important water tower on a national level, yet the difference in the orientation of these two hydro systems means that water availability is different on either side of the chain. According to the literature, several studies in Morocco have been carried out on the characterization of the physical parameters of watersheds through the application of DEMs and GIS techniques [5] [15] [16].

The Zat and Upper Draa basins have been the subject of several sectoral and localized studies [17] [18] [19]. However, there are few or almost no studies that address the effect of its physical characteristics on the abundance or scarcity of water resources in these two watersheds. This study attempts to focus on the relationship between surface water availability and the orographic, morphological and rainfall characteristics of these two watersheds through the intervention of the GIS and DEM, with a view to the management and conservation of water resources of these two basins. 


\section{Materials and Methods}

\subsection{Study Area}

The Zat basin is a tributary of the left bank of the Tensift River (Figure 1), between latitudes $31^{\circ} 9^{\prime} \mathrm{N}-31^{\circ} 33^{\prime} \mathrm{N}$ and longitudes $7^{\circ} 23^{\prime} \mathrm{W}-7^{\circ} 40^{\prime} \mathrm{W}$, it is drained by Zat River which forms with the Ourika River the two principal arms of the Hadjar River. It passes near Marrakech before flowing into the Tensift, it is bounded to the East by the Ghdat sub-basin, to the south by the High Atlas Mountains, to the North by the Tensift River and to the West by the Ourika sub-basin. The Zat basin is characterized by an arid to semi-arid climate downstream and sub-humid in the high mountains [20].

The Upper Draa basin is located in South-East Morocco (Figure 1), it constitutes the upstream part of the great basin of Morocco, administratively, the basin is integrated entirely or partially in three provinces Ouarzazate, Tinghir and Agdez From the hydrological point of view, the basin is characterized by a low-density hydrographic network with only two main watercourses having a perennial regime, it is mainly the Dades River which has its source in the high mountains of the Upper Draa with their only tributary, the M'goun River and the Draa River with these main temporary tributaries in particular: Fint, Ouarzazate, Imini, Iriri, Ounila and Mellah Rivers. From a climatic point of view, the basin is characterized by a subhumid climate in the high mountains and an arid climate in the areas at low altitudes. The latter is distinguished by relatively low rainfall, about $116 \mathrm{~mm} /$ year [21].

\subsection{Sampling}

From DEM, the following morphometric characteristics of the basin: perimeter;

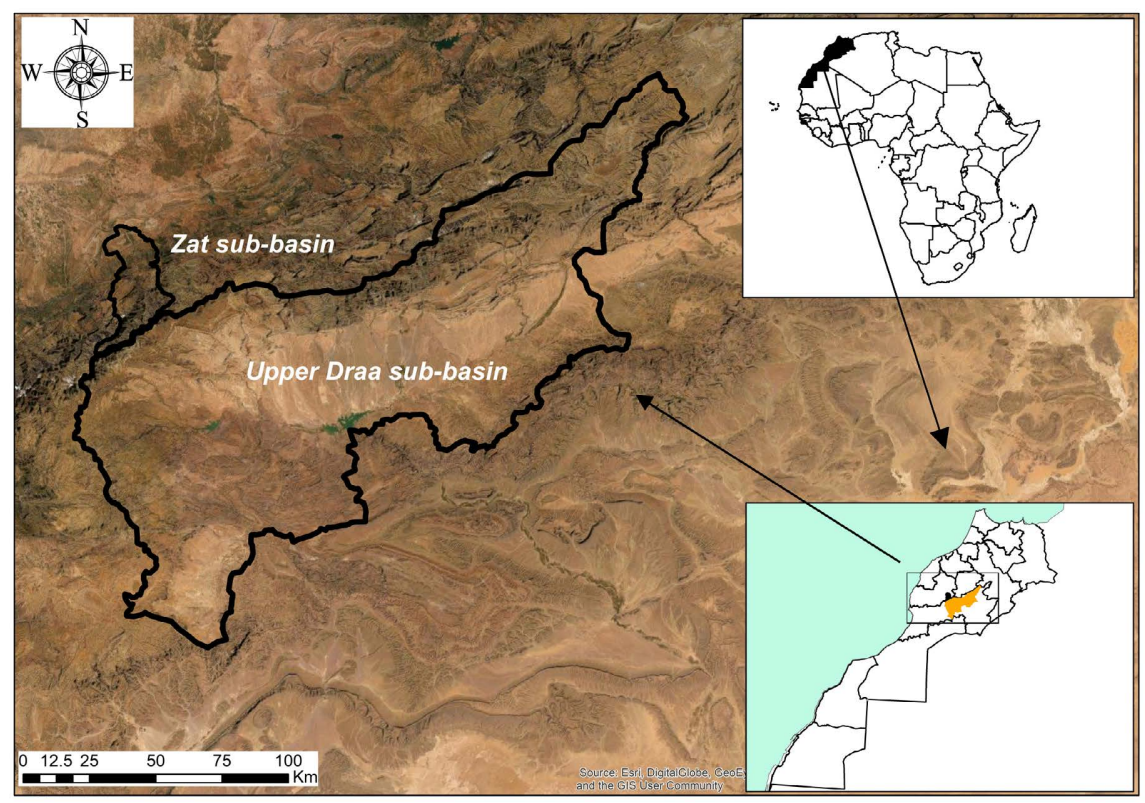

Figure 1. Geographical location of the Zat and Upper Draa basin. 
compactness coefficient; drainage density, altitude ranges, slope, aspect and hydrographic network have been extracted using the different functions available in spatial analyst extension tool of ArcGIS ${ }^{\infty}$ 10.2.2. In this study, six DEM scenes covering the study areas, generated from Shuttle Radar Topography Mission (SRTM) have been used, taken on May 23, 2018 with a spatial resolution of 30 $\mathrm{m}$. These DEM were available for free from (https://earthexplorer.usgs.gov/) and geo-referenced to the WGS84. The rainfall data of meteorological stations localized in the study areas of the period 2000-2020 were incorporated in order to quantify the effect of the morphometric characteristics on water distribution on either side of the High Atlas. The data has been downloaded from the Global Modelling and Assimilation Office (GMAO, MERRA-2).

The morphology of a basin affects the rain-flow relationship and conditions the shape of the hydrograph observed at the outlet. Several parameters are used to quantify morphological characteristics: The Gravelius compactness index " $K G$ " was defined as the ratio between the basin perimeter $(\mathrm{P})$ and the perimeter of a circle of the same area.

$$
\text { "KG = "'P" /("2" } \sqrt{(" n " ~) ~ " . A " ~) " ~ \approx ~ 0.28 . " P " ~ / " ~} \sqrt{\mathrm{A} "}
$$

where: $\mathrm{KG}$ is the Gravelius compactness index, $\mathrm{A}$ is the surface of the catchment area $\left[\mathrm{km}^{2}\right]$ and is $P$ the basin perimeter $[\mathrm{km}]$. The value of the index is close to 1 if the shape of the basin is quasi-circular (well drained) with a greater infiltration potential than those of elongated shape and equal to 1.12 if the basin is square, whereas it is lengthened if the index value exceeds 1.12 [22]. The Density of drainage "Dd" of a basin is a parameter that takes into account the flow, the stability of the hydrographic network and the type of surface runoff [23]. It depends on geology (structure and lithology), topographic characteristics of the basin, and to some extent, meteorological and anthropogenic conditions [24]. The drainage density Dd is the ratio between the total length of the watercourses and the total area of the basin:

$$
\mathrm{Dd}=\left(\sum \text { "tx.km") / "A. }\left(\mathrm{km}^{2}\right) "\right.
$$

To reconstitute the hydrographic network, we did follow several steps: fill of the spurious depressions (fill sinks); direction of flow (flow direction); accumulated flow (flow accumulation) and delineation of basins (watershed). The hydrography was generated from the accumulated flow, using the raster calculator tool of the spatial analyst extension of ArcGIS ${ }^{\varpi}$ 10.2.2, using a value of 500 (a value that provided a more representative hydrography) as the minimum number of cells for the generation of flow. The hydrographic network was ordered according to Strahler classification (1957) [25]. In addition, other morphometric characteristics have been processed in this study by using the spatial analyst extension tools of ArcGIS ${ }^{\circledast}$ 10.2.2, such as slope, elevation and aspect.

\section{Results and Discussion}

\subsection{Morphological and Hydrological Characteristics}

The analysis of the hydrological behavior of a watershed was done by quantify- 
ing several morphometric parameters summarized in Table 1. The Gravelius compactness index is about 1.76 for the Zat basin and 1.93 for the Upper Draa basin. The relatively high compactness of the latter gives the basin a more elongated shape than that of the Zat basin (Table 1). This situation favors for the Zat basin, a relative simultaneity of the collection of runoff water in the main rivers of the basin. Surface flows are reduced due to losses from infiltration and evaporation. The spatial and temporal movement of water through the Upper Draa basin increases the deficit in flow and this type of basin should experience very few cases of flooding along the banks of the rivers, even during periods of flooding [26].

The hydrographic network map (Figure 2(a) and Figure 2(b)) shows that the total length of all the rivers in the Upper Draa basin is about $2483 \mathrm{~km}$. These rivers are distributed over an area of $17,742 \mathrm{~km}^{2}$ which gives an average drainage density of about $0.14 \mathrm{~km} / \mathrm{km}^{2}$ (Table 1 ), this value suggest that the basin is characterized by a low density hydrographic network. These results contrast with the Zat basin, which is characterized by a relatively high drainage density of about $1.48 \mathrm{~km} / \mathrm{km}^{2}$.

Table 1. Morphological characteristics of the Zat and Upper Draa basin.

\begin{tabular}{ccc}
\hline Morphometric characteristic & Zat basin & Upper Draa basin \\
\hline Area $\left(\mathrm{km}^{2}\right)$ & 533 & 17,742 \\
Perimeter $(\mathrm{km})$ & 150 & 919 \\
Compactness index KG & 1.76 & 1.93 \\
Drainage density Dd & 1.48 & 0.14 \\
Length of main watercourses $(\mathrm{km})$ & 11.6 & 142.16 \\
Maximum altitude $(\mathrm{m})$ & 3920 & 4040 \\
Minimum altitude $(\mathrm{m})$ & 700 & 400 \\
\hline
\end{tabular}

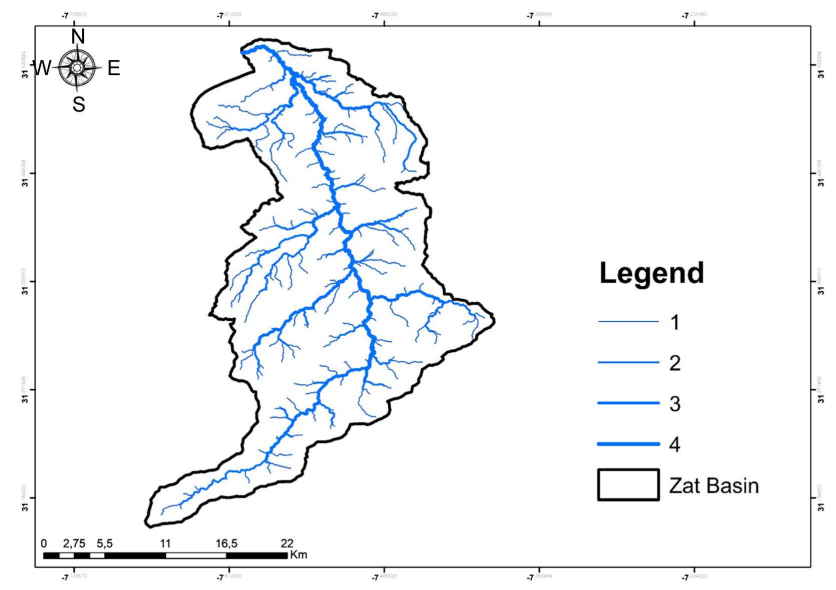

(a)

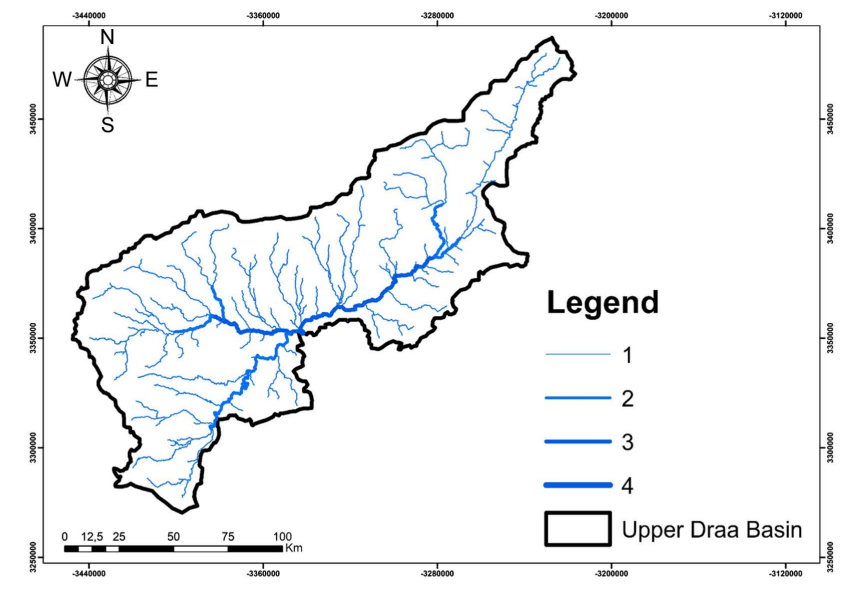

(b)

Figure 2. Hydrological map of Zat basin (a) and Upper Draa basin (b). 
The hydrological contrast observed in these hydro systems has an impact on the human use of surface water. Human populations were able to easily and continuously divert water from the Zat Rivers by the Seguias for domestic and agricultural reasons. This contrast affected the natural conditions offered for irrigation with the possibility of perennial crops in this basin, while the low surface water resources in the Upper Draa basin resulted in smaller cultivated areas and agricultural yields [5] [21].

\subsection{Geological Characteristics}

The Upper Draa basin is characterized by a diversified geological substrate (Figure 3(b)). They are composed essentially of schist, sandstone and quartzite on which rest a Precambrian formation of magmatic rocks composed of Upper Triassic shales containing evaporites such as halite and gypsum (about $24 \%$ of the watersheds) and Lower Jurassic (Liassic) limestone and dolomite which covers about $64 \%$ of the watershed [27]. The drainage of the High Atlas is characterized by highly permeable rocks (karst, limestone) that drain water to the porous deposits of the Quaternary of the Ouarzazate basin.

However, the Zat basin is composed of Cambrian, Acadian and Ordovician Paradoxidic shales with predominantly schistose facies, Tournaisian Upper Visean with predomi-nantly limestone facies, Permo-triassic sandstones and clays and Cenomanian and Senonian marl limestone structures (Figure 3(a)). Globally, the lithology of the Upper Draa basin is much more permeable than the Zat basin. This contrast in the nature of the substratum favors the abundance of surface water on the northern slope of the High At-las and accentuates the shortage on the southern slope. It has been established by several researchers that the substrate nature has an impact on the availability of water re-sources at the basin [5] [16] [21].

\subsection{Slope Exposure}

Slope exposure refers to the orientation of slopes relative to the sun, which

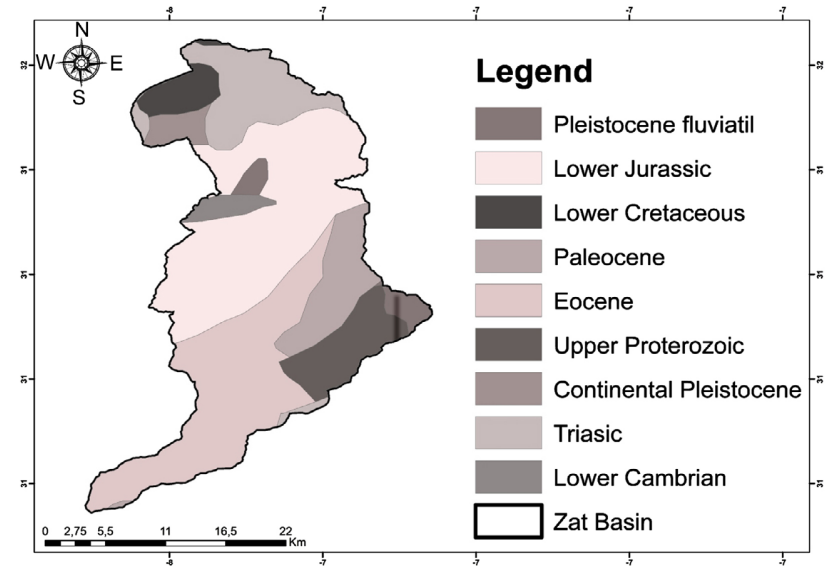

(a)

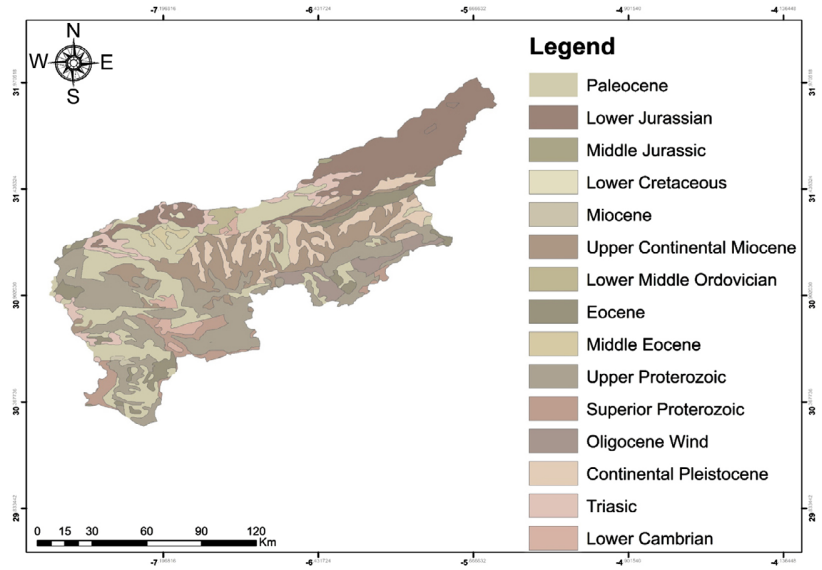

(b)

Figure 3. Geological map of Zat basin (a) and Upper Draa basin (b). 
reflects a shift in the duration of sunlight and the thermal intensity of radiation received on the ground per unit of area [21]. The southern slopes, called ubac, are characterized by a very low shade rate and high exposure to sunlight with low rainfall, which will increase the aridity of the soil. While the northern slopes are watered more and characterized by higher atmospheric humidity [21], this is particularly true in the Zat basin (Figure 4), where the slopes are deep and the slopes are mainly exposed to the north or northwest (30.42\%).

These slopes receive a low intensity of solar radiation, and some valleys are in the shade very early in the evening and quite late in the morning. This is especially true for the deepest, which even lose all the sunlight for a few weeks in winter. This attenuation of solar radiation allows the soil to retain moisture for a long time and reduces the evaporation capacity of the air, which could be significant at these latitudes. Moreover, the position of the Upper Draa basin on the southern slope of the High Atlas makes most of its slopes more exposed to the East and South-East (27.34\%), which will, therefore, lead to strong evaporation of surface water and aridity of the soil than in the Zat basin (Figure 4). [1] found the same results for the comparison between the Ourika and Marghène basins.

\subsection{Hypsometric Parameters}

The analysis of the altitude ranges of the study areas and their corresponding percentage shows that the dominant altitudes of the Zat basin are between 1600 $2400 \mathrm{~m}$, representing $43.51 \%$ of the total area of the basin (Figure 5(a)), coupled with an exposure of the northern and North-West slopes, favor significant rainfall inputs, that contrasts with the Upper Draa basin where the altitudes are not higher.

The hypsometric map of the Upper Draa basin (Figure 5(b)) shows a succession of altitude ranges from 1220 to $3600 \mathrm{~m}$, but most of the basin is located between 800 and $1600 \mathrm{~m}$. These lower altitudes in the Upper Draa basin, coupled with an opening to the south-east, consequently favors lower rainfall inputs compared to the Zat basin (Figure 5(a)).

Even areas with altitudes above $2000 \mathrm{~m}$ that would receive snowfalls occupy only $15.07 \%$ of the basin area, compared to $42.65 \%$ for the Zat basin. While areas

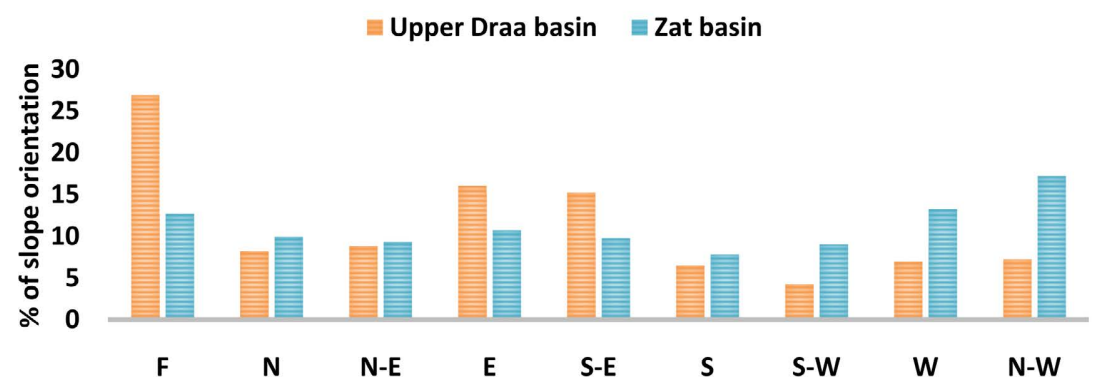

Figure 4. Representation of the percentages of slope orientations and their corresponding areas of the Upper Draa and Zat basin (F: Flat; N: North; N-E: North-East; E: East; S-E: South-East; S: South; S-W: South-West; W: West; N-W: North-West). 


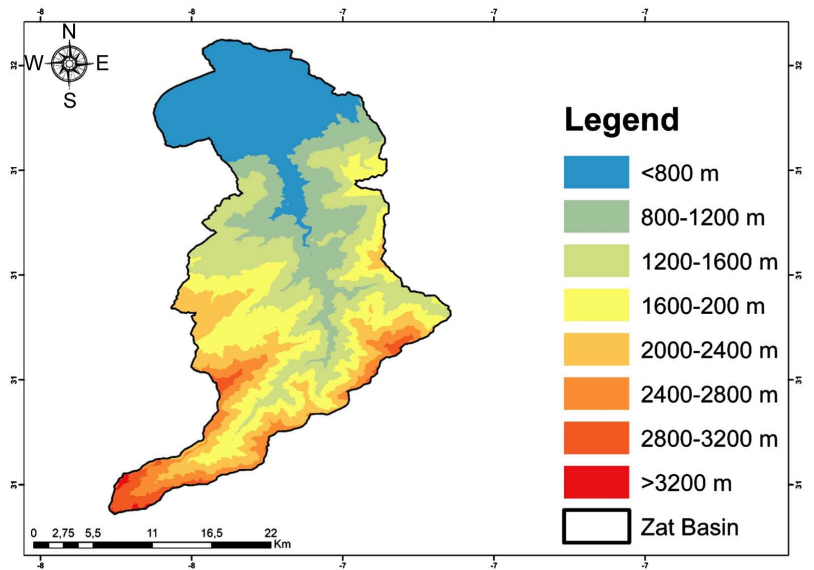

(a)

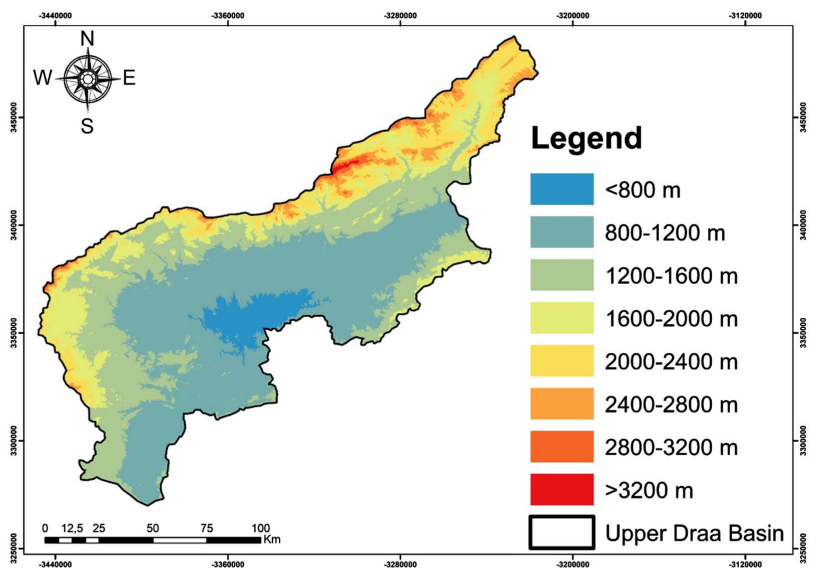

(b)

Figure 5. Hypsometric map of Zat basin (a) and Upper Draa basin (b).

above $2400 \mathrm{~m}$ (with higher snowfall) occupy only a restricted area in the Upper Draa basin, with $7.51 \%$ of the basin, compared to $22.69 \%$ in the Zat basin. These results were confirmed by [15] [16], where they highlighted those altitudes variations have an effect on rainfall rate, water infiltration and the accumulation of flow.

\subsection{Slope}

The topographic slope is a crucial parameter in any management and development study; its conditions drainage [5] [15] [20]. Indeed, its intensity directly affects the phenomena of infiltration, runoff and erosion, its shape, and the length over which it acts. The calculation of the slopes for the study areas, shows for Upper Draa basin the dominance of areas with a low slope (0\% - 10\%) covering an area of $28,778 \mathrm{~km}^{2}$ which corresponds to $81 \%$ of the basin, they are essentially located in the southern part and along the Draa River. On the other hand, areas with medium to steep slopes vary between $10 \%$ and $35 \%$ and represent only $20 \%$ of the basin's territory and are much localized, especially at the level of the tributaries of the upstream part of the basin (Figure 6(b)). These areas are prone to erosion.

Although, the slope calculation for the Zat basin found that the slopes of the main basin are not particularly steep ( $0 \%$ to $5 \%$ ); the speed and severity of flows are mainly governed by the steepest slopes of the tributaries and slopes. Almost all tributaries flow into the main river with very steep slopes. The steepest valleys are located upstream of the basin with slopes that reach, in places, values of $30 \%$ to $40 \%$ (Figure 6(a)). These differences in slope values favor run off over infiltration and evaporation in the Zat basin due to high flow velocities. [5] found the same results for the comparison between two watersheds of High Atlas of Morocco (Ourika and Marghène).

\subsection{Pluviometry}

All these differences in morphology, substrate type, hypsometric variations and 
exposure to humid air masses have led to a strong contrast in water availability between the two basins studied. Indeed, the comparison between the annual precipitation of the hydrological stations of the two basins over the period 2000-2020 (Figure 7) illustrates that the tributaries of the Zat basin, such as: Taferiate, Aghbalou and Sidi Rahal, collected an annual average of $332 \mathrm{~mm}$, which far exceeds the precipitation of the basin of the Haut Draa $(124 \mathrm{~mm})$ during the same period, namely in: Mansour Eddahbi dam, Agouilal, Assaka, M'semrir and Ouarzazate. The differences between the above-mentioned physical parameters are largely responsible for this rainfall contrast on either sides of the high Atlas range, and induce a second contrast in surface runoff on the two basins, which is accentuated by other morphometric parameters such as shape, slopes, lithology and altitude. This contrast in precipitation has been highlighted by [5] and [20].

For the Zat basin, analysis of rainfall data from meteorological stations during the period 2000-2020 revealed an estimated average significant rainfall of 332 $\mathrm{mm}$. Annual inflows vary from $160 \mathrm{~mm}$ (in 1999-2000) to $524 \mathrm{~mm}$ (2010-2011).

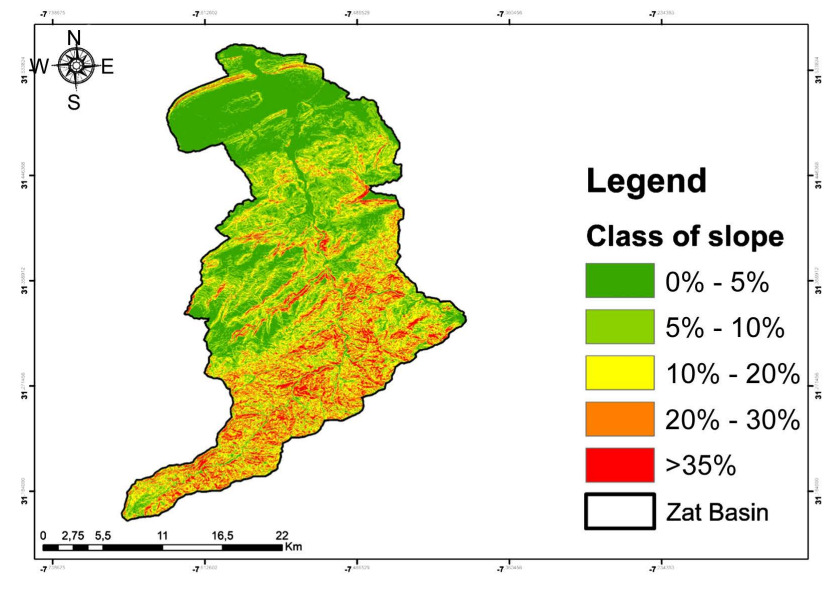

(a)

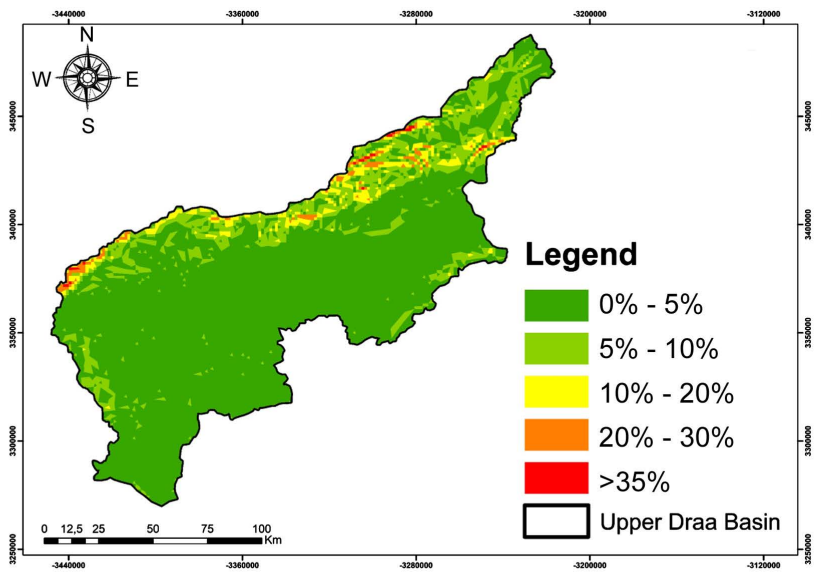

(b)

Figure 6. Slope map of Zat basin (a) and Upper Draa basin (b).

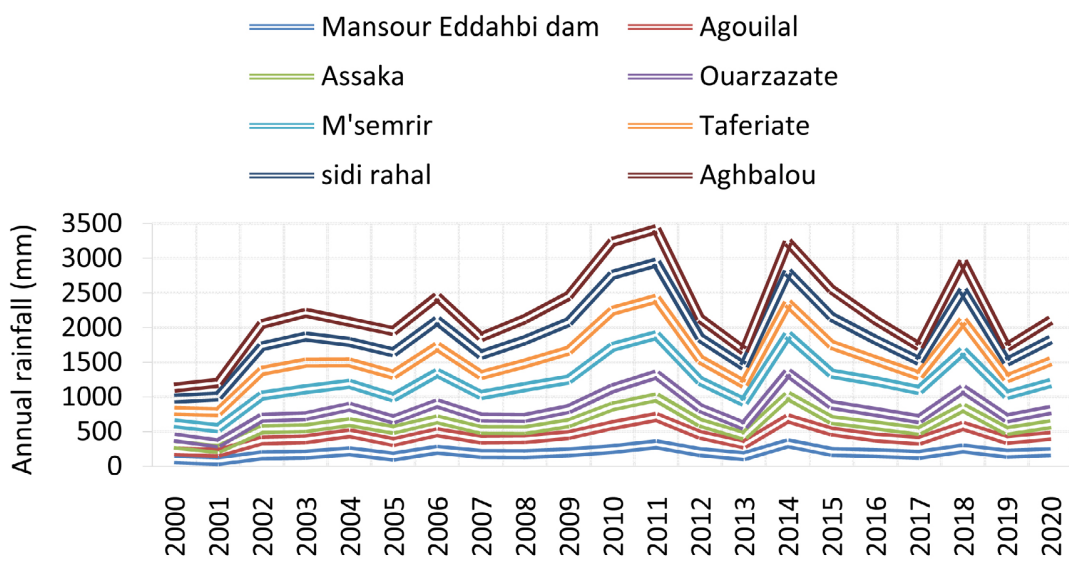

Figure 7. Annual rainfall variation in the two basins of the high Atlas (Zat and Upper Draa) during the period 2000-2020. 
The coefficient of variation is about 5\%. This shows a low irregularity of precipitation in these semi-arid environments (Figure 7 ). The relatively high amounts recorded for these stations reflect the importance of altitude, and especially the exposure of the watershed to moist air currents. The situation is changing completely in the Upper Draa basin, since the average annual precipitation is about $195 \mathrm{~mm}$ during the period 2000-2020. The maximum recorded was $332 \mathrm{~mm}$ in 2014-2015, while the minimum was only $76 \mathrm{~mm}$ in 2001-2002 (Figure 7). The coefficient of variation of this annual precipitation is about $40 \%$. It is significantly higher than that recorded in the Zat basin.

\section{Conclusion}

The Zat basin and the Upper Draa basin are two hydro systems contrasted by their morphological, geological and orographic characteristics, the combination of these characteristics clearly expresses the abundance and mobilization of surface water in the Zat basin with high altitudes and slopes, associated with valleys exposed to wet-land masses. While water scarcity with low rainfall input and soil aridity is observed in the Upper Draa basin, with relatively low elevations and slopes that dominate in its territory accompanied by an opening towards the East and South East. The GIS tools and the contribution of DEM used in the study are useful to identify this contrast between these two watersheds. It should be noted that despite all these advantages and the remarkable contributions of digital field models, although they are very powerful analytical tools, they will not solve all physiographic problems. Complementary approaches based on the reality on the ground are needed.

\section{Acknowledgements}

This study was financed by the Museum of Natural History of Marrakesh, and partly supported by the German Federal Ministry of Education and Research (BMBF) through funding the project Salidraa جو within the framework of the Strategy "Research for Sustainability" (FONA) www.fona.de/en as part of its Social-Ecological Research funding priority, funding no 01 UU1906.

\section{Conflicts of Interest}

The authors declare no conflicts of interest regarding the publication of this article.

\section{References}

[1] Louise, R. (2007) Water, Source of Conflict [L'eau, source de conflits.]. Lex Electronica, $12,5 \mathrm{p}$.

[2] Mutin, G. (2009) The Arab World Facing the Water Challenge: Stakes and Conflicts [Le monde arabe face au défi de l'eau: Enjeux et conflits.]. HAL-Version 2.

[3] Magesh, N.S. and Chandrasekar, N. (2012) GIS Model-Based Morphometric Evaluation of Tamiraparani Subbasin, Tirunelveli District, Tamil Nadu, India. Arabian Journal of Geosciences, 7, 131-141. https://doi.org/10.1007/s12517-012-0742-Z 
[4] Houdret, A. (2008) Les conflits autour de l'eau au maroc: Origines sociopolitiques et écologiques et perspectives pour transformation des conflits. Thèse de doctorat en sciences politiques, Université Duisburg-Essen et l'Université Paris 8, Duisburg, Allemagne, $74 \mathrm{p}$.

[5] Saidi, M., Agoussine, M. and Daoudi, L. (2006) Effet de la morphologie et de l'exposition sur les ressources en eau superficielle de part et d'autre du haut atlas (Maroc); exemple des bassins versants de l'ourika et du marghène. Bulletin de L'Institut Scientifique, 28, 41-49.

[6] Aher, P.D., Adinarayana, J. and Gorantiwar, S.D. (2014) Quantification of Morphometric Characterization and Prioritization for Management Planning in SemiArid Topics of India: A Remote Sensing and GIS Approach. Journal of Hydrology, 511, 850-860. https://doi.org/10.1016/j.jhydrol.2014.02.028

[7] Esper Angillieri, M.Y. (2008) Morphometric Analysis of Colangui River Basin and Flash Flood Hazard, San Juan, Argentina. Environmental Geology, 55, 107-111. https://doi.org/10.1007/s00254-007-0969-2

[8] Gebrehiwot, S.G., Iistedt, U., Gardenas, A.I. and Beshop, K. (2011) Hydrological Characterization of Watersheds in the Blue Nile Basin, Ethiopia. Hydrology and Earth System Sciences, 15, 11-20. https://doi.org/10.5194/hess-15-11-2011

[9] Ameri, A.A., Porghasemi, H.R. and Cerda, A. (2018) Erodibility Prioritization of Sub Watersheds Using Morphometric Parameters Analysis and Its Mapping: A Comparison among TOPSIS, VIKOR, SAW, and CF Multi-Criteria Decision Making Models. Science of the Total Environment, 613-614, 1385-1400. https://doi.org/10.1016/j.scitotenv.2017.09.210

[10] Silva, J.M.A., Pruski, F.F., Silva, D.D. and Cecilio, R.A. (2006) Metodologia para obtenção do hidrograma de escoamento superficial em encostas e canais. Parte I: Descenvolvimento e avaliação. Engenharia Agricola, 26, 695-703. https://doi.org/10.1590/S0100-69162006000300005

[11] Abdulkareem, J.H., Pradhan, B., Sulaiman, W.N.A. and Jamil. N.R. (2018) Quantification of Runoff as Influenced by Morphometric Characteristics in a Rural Complex Catchment. Earth Systems and Environment, 2, 145-162. https://doi.org/10.1007/s41748-018-0043-0

[12] Mudashiru, R.B., Salami, A.W. and Bilewu, S.O. (2018) Evaluation of Methods of Peak Runoff Determination Using Catchment Characteristics for Jere Sub-Basin, Gurara River Basin, North Central Nigeria. Journal of Engineering Research, 15, 26-41. https://doi.org/10.24200/tjer.vol15iss1pp26-41

[13] Subyani, A.M., Qari, M.H. and Matsah, M.I. (2010) Digital Elevation Model and Multivariate Statistical Analysis of Morphometric Parameters of Some Wadis, Western Saudi Arabia. Arabian Journal of Geosciences, 5, 147-157. https://doi.org/10.1007/s12517-010-0149-7

[14] Belhouari, S. (2019) Secteur de l'eau au maroc: Pourquoi faut-il miser sur une gouvernance juste et durable? Fondation Heinrich Böll Afrique du Nord, Rabat.

[15] Khafaoui, A. and Saidi, M. (2014) Apport des outils de sig dans la cartographie d'un bassin versant montagnard: cas de L'oued R'Dat (Haut Atlas de Marrakech, Maroc). Colloque sur le Système National d'Information d'Eau, Rabat.

[16] Argaz, A., Ouahman, B., Darkaoui, A., Bikhtar, H., Yabsa, K. and Laghzal, A. (2019) Application of Remote Sensing Techniques and Gis-Multicriteria Decision Analysis for Groundwater Potential Mapping in Souss Watershed, Morocco. Journal of Materials and Environmental Science, 10, 411-421.

[17] Mostakim, L., Guennoun, F.Z., Fetnassi, N. and Ghamizi, M. (2021). Analysis of 
Floristic Diversity of the Forest Ecosystems of the Zat Valley-High Atlas of Morocco: Valorization and Conservation Perspectives. Journal of Advanced Biotechnology and Experimental Therapeutics, 5, 126-135. https://doi.org/10.5455/jabet.2022.d102

[18] Mostakim, L., Fetnassi, N. and Ghamizi, M. (2020a) Floristic Study and Assessment of the Environmental Factors Governing the Distribution of Riparian Plants in the Zat Sub-Basin: Tensift Watershed, Morocco. Journal of Animal and Plant Sciences, 45, 7900-7915.

[19] Mostakim, L., Fetnassi, N., Rassam, H., Benaissa, H., Berger, E. and Ghamizi, M (2020b) Assessment of Aquatic and Semi-Aquatic Plants in Arid Regions: Testing Factors Affecting Riparian Plant Distribution in the Draa Basin, Morocco. EurAsian Journal of BioSciences, 14, 4735-4741.

[20] Ait Mlouk, M., Algouti, A. and Ourhzif, Z. (2015) Utilisation des images satellitaires du Landsat dans l'étude de la dégradation des berges des oueds: Exemple des berges des oueds Rdat, Zat et Tensift lors de la crue de Novembre 2014 (Marrakech, Maroc). Journal of Applied Sciences Research, 27, 119-129.

[21] Agoussine, M. and Bouchaou, L. (2004) Major Problems of Water Management in Morocco [Les problèmes majeurs de la gestion de l'eau au Maroc.]. Sécheresse, 15, 187-194.

[22] Musy, A. (2005) Cours d'hydrologie générale. Laboratoire d'hydrologie et Aménagements (HYDRAM), Institut des Sciences et Technologies de l'Environnement (ISTE), Ecole Polytechnique Fédérale (EPFL).

[23] Liamas, J.M. (1993) Hidrología General. Edición Espanola, Servicio Editorial Universidad del País Vasco, 635 p.

[24] Musy, A. and Higy, C. (2004) Hydrology, a Science of Nature [Hydrologie, une science de la nature.]. PPUR Presses Polytechniques, Lausanne, $314 \mathrm{p}$.

[25] Strahler, A.N. (1957) Quantitative Analysis of Watershed Geomorphology. Eos, Transactions American Geophysical Union, 38, 913-920. https://doi.org/10.1029/TR038i006p00913

[26] Musy, A. and Laglaine, V. (1992) Hydrologie générale. École Polytechnique Fédérale de Lausanne, Lausanne, $534 \mathrm{p}$.

[27] Cappy, S., Klose, S., Hoffmann, H., Osterhold, V. and Bell, B. (2008) Hydrogeology of the Assif-n-Ait Ahmed Catchment. In: Schulz, O. and Judex, M., Eds., IMPETUS Atlas Morocco, Department of Geography, University of Bonn, Bonn, 49-50. 